\title{
Immunological abnormalities in patients with untreated retinal vasculitis
}

\author{
DENIS WAKEFIELD, JOAN EASTER, AND RONALD PENNY
}

From the Schools of Pathology and Medicine, University of New South Wales; Department of Immunology, St Vincent's Hospital; and the Uveitis Research Clinic, Sydney Eye Hospital, Sydney, Australia

SUMmary Peripheral blood immunological features were assessed in 21 patients with clinical and angiographic evidence of retinal vasculitis (RV). Abnormalities of humoral and cellular immunity were frequent in this group of patients. Lymphopenia was the most common immunological abnormality, being present in $76 \%$ of patients at presentation $(\mathrm{p}<0.05)$. Peripheral blood $\mathrm{T}$ and $\mathrm{B}$ cells were decreased with a normal helper (OKT4) to suppressor (OKT8) T cell ratio in 11 patients tested (five with Behçet's syndrome and six with idiopathic RV). Significantly increased concentrations of serum immune complexes were present in $55 \%$ of patients $(p<0.05)$. Results of the present study indicate the frequent association of peripheral blood immunological abnormalities in patients with active RV and indicate the possible role of immunological mechanisms in its pathogenesis.

The retina is involved in several systemic autoimmune diseases in which the basic pathology is a vasculitis. Retinal vasculitis (RV) is the basic histopathological lesion of Behçet's syndrome' and also occurs in polyarteritis nodosa, ${ }^{2}$ giant cell arteritis, ${ }^{34}$ and less frequently in SLE. ${ }^{5.8}$ The clinical similarity between RV in this group of diseases and the experimental animal model of RV produced in rabbits ${ }^{10}$ suggests that immune complexes may be involved in the pathogenesis. ${ }^{11}$

There has been limited opportunity for the study of immune mechanisms in retinal vasculitis owing to the rarity of the condition and difficulties associated with studying a large group of patients with untreated disease. We present here the results of a study of 21 patients with RV investigated at the onset of their disease before beginning treatment. The results highlight the frequency of immunological abnormalities in untreated patients with RV.

\section{Material and methods}

\section{PATIENT SELECTION}

Twenty-one patients referred to the Uveitis Research Clinic at Sydney Eye Hospital or the Department of

Correspondence to Dr D Wakefield, School of Pathology, University of New South Wales, PO Box 1, Kensington, NSW, Australia.
Immunology, St Vincent's Hospital, were investigated. All patients were seen independently by at least two ophthalmologists and had fluorescein angiograms that were independently reported to be consistent with the diagnosis of RV.

IMMUNOLOGICAL INVESTIGATIONS

Using standard radial immunodiffusion techniques we determined levels of the following serum proteins: IgG, IgM, IgA, C3, and C4. IgE levels were measured by radioimmunoassay (Pharmacia). Functional assessment of the classical and alternative pathways of complement were done by measuring the reciprocal of the titre of serum lysing $50 \%$ of sensitised sheep red blood cells (CH50) ${ }^{13}$ and sensitised rabbit erythrocytes (PH50) ${ }^{14}$ respectively. Complement assays were performed by the laboratories of Dr J Zeigler and Dr J Charlesworth at Prince of Wales and Prince Henry Hospitals, Sydney.

Serum autoantibodies (antinuclear (ANA), gastric parietal cell (GPC), smooth muscle (SM), and reticulin) were determined by an indirect immunofluorescence technique with a composite block of rat liver and stomach and mouse kidney and stomach as the substrate. DNA binding was determined by the anti-DNA assay kit (Amersham). Serum immune complexes ( $\mathrm{Clq}$ binding assay and quantitative 
cryoglobulin) were determined by the methods of Andrews et al. ${ }^{11}$ All patients were examined for the presence of serum cryoglobulinaemia, while 11 patients were tested in the $\mathrm{C} 1 \mathrm{q}$ binding assay.

Peripheral blood $\mathrm{T}$ cell numbers and the percentage of $\mathrm{T}$ cells in the two major subsets were analysed by indirect immunofluorescence using monoclonal antibodies (OKT3, 4, and 8; Ortho Diagnostics Systems). ${ }^{15}$

Retinal autoantibodies were detected by indirect immunofluorescence on fresh human retina, removed from previously normal eyes within 12 hours of death. The retina was carefully dissected free from the choroid, folded on itself several times, placed in OCT (Ames Co.), snap frozen in isopentane and solid $\mathrm{CO}_{2}$, and processed as previously described. ${ }^{16}$

\section{AETIOLOGICAL INVESTIGATIONS}

All patients had the following examinations: a full blood count, erythrocyte sedimentation rate, serum and urine biochemical screen, liver function tests, calcium and angiotensin converting enzyme estimations, serological tests for syphilis, toxoplasma, toxocara, cytomegalovirus, herpes simplex, influenza A and $\mathrm{B}$, and adenovirus. Routine chest radiology was performed.

\section{Results}

The clinical features of patients with untreated RV are summarised in Table 1. The mean age of onset was $35 \cdot 0 \pm 11 \cdot 3$ years, range $17-54$ years. There were
12 females in the study population with a mean age of 38.1 (SD 11.5) years (range 20-54 years) and nine males with a mean age of onset of 31.0 (SD 10.3) years (range 17-44 years). The control population consisted of 161 healthy subjects.

\section{CLINICAL FEATURES}

Diagnosis was based on the clinical features with supporting angiographic findings. The clinical features used to diagnose RV were based on those described by ffytche. ${ }^{17}$ Patients were considered to have central RV if they had evidence of oedema of the optic nerve head and adjacent retina with or without macular oedema and decreased visual acuity. ${ }^{18}$ Patients with peripheral RV had evidence of vascular inflammation without optic nerve head involvement and usually confined to veins more than two disc diameters away from the optic nerve. Fourteen patients (eight males and six females) had peripheral RV with a mean age of onset of 32.9 (SD $11.0)$ years (range 17-47 years). In two cases there was combined central and peripheral RV (one male and one female). Five patients (all of whom were female) had central RV with a mean age of 39.0 (SD $11.5)$ years (range 21-54). The fundal appearance in central RV was characterised by disc oedema with venous dilatation, perivenular haemorrhages, and vascular sheathing confined to the region of the optic disc. Macular oedema with decreased visual acuity was present in all five patients. Hypertension and raised intracranial pressure were excluded. All cases of central RV cases ( 9 and 18) had associated uveitis

Table 1 Clinical features in 21 patients with retinal vasculitis

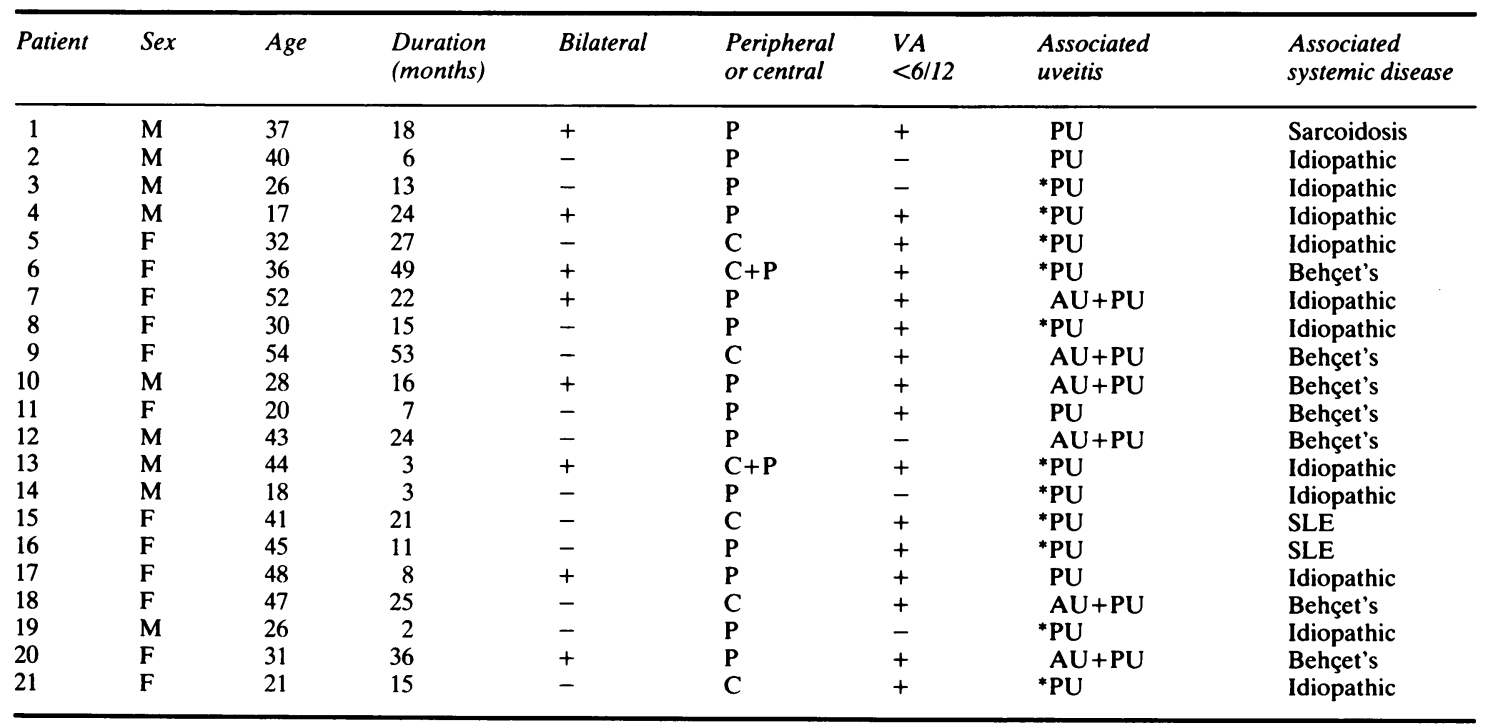

$\mathrm{AU}=$ anterior uveitis. $\mathrm{PU}=$ posterior uveitis. $\mathrm{SLE}=$ systemic lupus erythematosus. ${ }^{*} \mathrm{PU}=$ chorioretinal lesions. 
with vitreous inflammatory cells. One patient with Behçet's syndrome (case 18) developed severe thrombotic glaucoma requiring enucleation. All patients with central and central combined with peripheral RV had decreased visual acuity at presentation (Table 1).

\section{DISEASE ASSOCIATIONS}

Relevant associated diseases were present in 10 of 21 patients with RV (Table 1). Behçet's syndrome was the most common disease association, being present in seven patients (five females). It was diagnosed by the presence of oral and genital ulcers and the absence of any other cause. ${ }^{19} \mathrm{RV}$ was confined to the peripheral veins in four patients with Behçet's syndrome (Fig. 1), with two patients having central $\mathrm{RV}$ and one patient having panretinal involvement (Fig. 2).

Two patients had SLE diagnosed on the basis of American Rheumatism Association criteria ${ }^{20}$ and the presence of significantly raised titres of DNA antibodies. Both patients were females and had symptoms suggestive of SLE for the previous five years. In each case RV was severe, with decreased visual acuity.

\section{IMMUNOLOGICAL INVESTIGATIONS}

Serum IgG levels were significantly reduced in five patients (range 6.1-6.8 g/l $(p<0 \cdot 05)$. One patient had an increased serum $\operatorname{IgA}$, while four had significantly raised serum IgM levels $(p<0.05)$, and six patients had raised serum IgE levels compared with the control population $(\mathrm{p}<0 \cdot 05)$.

Serum complement levels (C3 and $\mathrm{C} 4)$ were

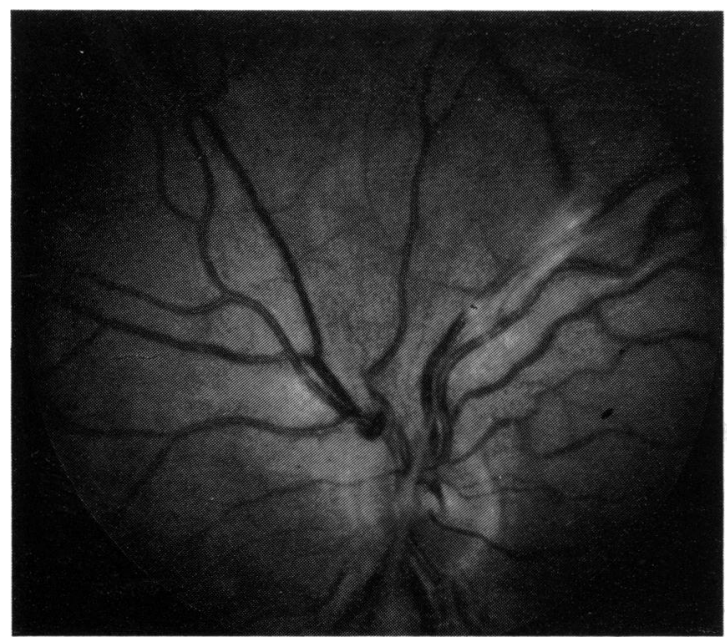

Fig. 1 Patient 11. A 20-year-old female with recurrent mouth and genital ulcers. Fundus photograph of peripheral retinal vasculitis involving the superior temporal veins. normal or slightly increased in all patients with RV (Table 2). Increased C4 levels were detected in the serum of eight patients tested, while $\mathrm{C} 3$ levels were raised in only one patient, who also had an increased $\mathrm{C} 4$ level. The mean C3 level was 1.3 (SD 0.3) g/l (range 0.9-2.0) and for $\mathrm{C} 4$ the mean was 0.3 (SD 0.1)

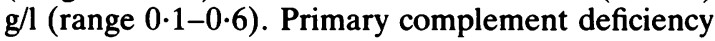
was excluded, as all patients had a normal or raised CH50 (mean 286 (SD 64) units, range 200-400).

Autoantibodies were present in the serum of nine patients (Table 2). Three patients (Nos. 1, 7, and 13) had low titre reticulin antibodies $(1 / 10)$, while an additional three patients (Nos. 3, 4, and 17) had low titre smooth muscle antibodies $(\leqslant 1 / 40)$. Significantly raised serum autoantibody titres were present in three patients, two with SLE (cases 15 and 16) who had raised antinuclear antibodies and increased DNA binding before treatment, one of whom also had a high titre of gastric parietal cell antibodies and a third patient (case 8) with idiopathic RV had a rheumatoid factor titre of $1 / 80$. None of the five patients or nine controls tested had autoantibodies to human retina by indirect immunofluorescence.

A comparison of the immunoglobulin abnormalities in different aetiological groups of patients with $\mathrm{RV}$ is summarised in Table 3, which demonstrates the increased frequency of peripheral blood immunological abnormalities in patients with idiopathic RV and Behçet's syndrome. Seven patients had significantly raised cryoglobulin levels when compared with controls $(p<0 \cdot 005)$. Of these, three had Behçet's syndrome, three had idiopathic RV, and one SLE (Table 3). The mean C1q binding level was $12 \cdot 4$ (SD $7 \cdot 3$ )\% (range $5-40 \%$ ) and this was significantly increased in comparison with the control group (mean 6.5 (SD 5.6)\%, range 1-18\%). Six patients had raised $\mathrm{Clq}$ binding levels, three with Behçet's

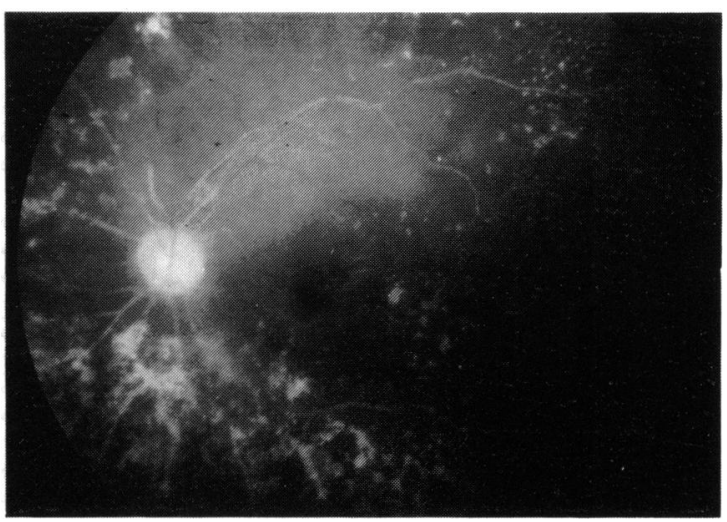

Fig. 2 Patient 6. A 36-year-old female with Behçet's syndrome. The patient has panuveitis with central and peripheral retinal vasculitis. 
Table 2 Immunological findings in 21 patients with retinal vasculitis

\begin{tabular}{|c|c|c|c|c|c|c|c|c|c|c|}
\hline \multirow[t]{2}{*}{ Patient } & \multirow{2}{*}{$\begin{array}{l}E S R \\
(\mathrm{~mm} / \mathrm{h})\end{array}$} & \multirow{2}{*}{$\begin{array}{l}\text { Lymphocytes } \\
\text { absolute no. } \\
\text { (cells/mm } \mathrm{mm}^{3} \text { ) }\end{array}$} & \multicolumn{4}{|c|}{ Immunoglobulin level } & \multicolumn{3}{|c|}{ Complement } & \multirow[t]{2}{*}{ Autoantibodies } \\
\hline & & & $\begin{array}{l}\lg G \\
(g / l)\end{array}$ & $\begin{array}{l}\lg A \\
(g / l)\end{array}$ & $\begin{array}{l}\operatorname{Ig} M \\
(g / l)\end{array}$ & $\begin{array}{l}\lg E \\
(U / \mathrm{ml})\end{array}$ & $\begin{array}{l}C 3 \\
(g / l)\end{array}$ & $\begin{array}{l}C 4 \\
(g / l)\end{array}$ & $\begin{array}{l}\text { CH50 } \\
\text { (units) }\end{array}$ & \\
\hline 1 & 5 & 1742 & $15 \cdot 0$ & $1 \cdot 1$ & $1 \cdot 5$ & 120 & 0.9 & 0.4 & 260 & Retic 1/10 \\
\hline 2 & 12 & 1380 & $8 \cdot 7$ & $2 \cdot 7$ & 0.9 & 60 & $1 \cdot 5$ & $0 \cdot 3$ & 240 & \\
\hline 3 & 1 & 1420 & $6 \cdot 6$ & 0.9 & $3 \cdot 0$ & 30 & $1 \cdot 1$ & $0 \cdot 2$ & 200 & SM 1/10 \\
\hline 4 & 13 & 1346 & $12 \cdot 0$ & 1.6 & 0.9 & 317 & 1.4 & $0 \cdot 3$ & 243 & SM 1/10 \\
\hline 5 & 6 & 1506 & $7 \cdot 3$ & $1 \cdot 1$ & $0 \cdot 8$ & 6 & $1 \cdot 2$ & $0 \cdot 3$ & 375 & - \\
\hline 6 & 21 & 960 & $10 \cdot 0$ & $2 \cdot 1$ & $3 \cdot 5$ & 80 & $1 \cdot 1$ & 0.4 & NT & - \\
\hline 7 & 12 & 880 & $6 \cdot 1$ & 1.6 & $1 \cdot 1$ & 70 & 2.0 & 0.6 & 400 & Retic 1/10 \\
\hline 8 & 3 & 840 & $10 \cdot 0$ & $1 \cdot 2$ & $1 \cdot 3$ & 68 & $1 \cdot 2$ & 0.4 & 234 & RF $1 / 80$ \\
\hline 9 & 12 & 1125 & 6.8 & 1.2 & $1 \cdot 1$ & 220 & $1 \cdot 0$ & $0 \cdot 3$ & NT & - \\
\hline 10 & 4 & 670 & $16 \cdot 0$ & $4 \cdot 0$ & $2 \cdot 0$ & 218 & 0.9 & 0.2 & 367 & - \\
\hline 11 & 1 & 1820 & 8.5 & $1 \cdot 5$ & $2 \cdot 7$ & 18 & $1 \cdot 2$ & $0 \cdot 3$ & 246 & - \\
\hline 12 & 7 & 1230 & $12 \cdot 5$ & 1.5 & $1 \cdot 7$ & 108 & $1 \cdot 3$ & $0 \cdot 2$ & $>400$ & \\
\hline 13 & 5 & 1170 & $7 \cdot 6$ & $2 \cdot 4$ & $0 \cdot 8$ & 730 & 1.2 & 0.4 & 225 & Retic 1/10 \\
\hline 14 & 1 & 1112 & $11 \cdot 2$ & 1.6 & $1 \cdot 3$ & 240 & 1.4 & $0 \cdot 2$ & 280 & 一 \\
\hline 15 & 4 & 1300 & $8 \cdot 3$ & $2 \cdot 4$ & 1.4 & 140 & 1.0 & $0 \cdot 1$ & 200 & $\begin{array}{l}\text { ANA } 1 / 640 \text {, DNA } 30 \text {, } \\
\text { GPC } 1 / 640\end{array}$ \\
\hline 16 & 14 & 2240 & $9 \cdot 3$ & $1 \cdot 4$ & $1 \cdot 0$ & 146 & 1.5 & 0.4 & 340 & ANA $1 / 160$, DNA 24 \\
\hline 17 & 21 & 1600 & $13 \cdot 0$ & $3 \cdot 1$ & 0.9 & 35 & $1 \cdot 3$ & $0 \cdot 2$ & 294 & ANA $1 / 40$, SM $1 / 10$ \\
\hline 18 & 12 & 260 & $6 \cdot 7$ & $2 \cdot 0$ & 0.9 & 120 & $1 \cdot 4$ & $0 \cdot 2$ & 340 & - \\
\hline 19 & 2 & 860 & $12 \cdot 0$ & $1 \cdot 3$ & $1 \cdot 2$ & 80 & 1.6 & $0 \cdot 3$ & NT & - \\
\hline 20 & 6 & 1260 & 6.7 & $1 \cdot 1$ & $0 \cdot 8$ & 334 & $1 \cdot 5$ & 0.4 & 280 & - \\
\hline 21 & 18 & 840 & $11 \cdot 0$ & $1 \cdot 2$ & $2 \cdot 3$ & 125 & $1 \cdot 5$ & 0.4 & 320 & - \\
\hline mean $\pm 2 S D$ & $\begin{array}{r}9 \\
\pm 6\end{array}$ & $\begin{array}{l}1217^{*} \\
\pm 438\end{array}$ & $\begin{array}{r}9 \cdot 8 \\
\pm 2 \cdot 8\end{array}$ & $\begin{array}{r}1.8 \\
\pm 0.8\end{array}$ & $\begin{array}{r}1.5 \\
\pm 0 \cdot 8\end{array}$ & $\begin{aligned} & 174^{*} \\
\pm & 175\end{aligned}$ & $\begin{array}{r}1 \cdot 3 \\
\pm 0.3\end{array}$ & $\begin{array}{r}0 \cdot 3 \\
\pm 0 \cdot 1\end{array}$ & $\begin{array}{r}286 \\
\pm 64\end{array}$ & \\
\hline $\begin{array}{l}\text { Controls } \\
(n=161) \\
\text { mean } \pm 2 S D\end{array}$ & $\begin{array}{r}11 \\
\pm 9\end{array}$ & $\begin{array}{r}2920 \\
\pm 765\end{array}$ & $\begin{array}{r}10 \cdot 9 \\
\pm 3 \cdot 6\end{array}$ & $\begin{array}{r}2 \cdot 0 \\
\pm 1 \cdot 8\end{array}$ & $\begin{array}{r}1.3 \\
\pm 0 \cdot 8\end{array}$ & $\begin{array}{r}45 \\
\pm 103\end{array}$ & $\begin{array}{r}1 \cdot 1 \\
\pm 0 \cdot 6\end{array}$ & $\begin{array}{r}0 \cdot 2 \\
\pm 0 \cdot 1\end{array}$ & $\begin{array}{r}300 \\
\pm 100\end{array}$ & \\
\hline
\end{tabular}

Abnormal results are printed in bold face.

${ }^{*} p \leqslant 0.05$ (patients with RV compared with controls, Student's $t$ test).

$\mathrm{NT}=$ not tested. $\mathrm{RF}=$ rheumatoid factor. $\mathrm{GPC}=$ gastric parietal cell. Retic=reticulin antibody. $\mathrm{ANA}=$ antinuclear antibody. $\mathrm{SM}=$ smooth muscle antibody. DNA=DNA binding.

SI conversion: lymphocytes $/ \mathrm{mm}^{3} \times 10^{6}=$ lymphocytcs $/ . \mathrm{U} / \mathrm{ml} \times 1000=\mathrm{U} / 1$.

syndrome (cases 11,12 , and 18), two with idiopathic RV (cases 3 and 13), and one SLE (case 16). Five patients had both increased cryoglobulins and $\mathrm{C} 1 \mathrm{q}$ binding. Four of the seven RV patients with Behçet's syndrome had increased circulating immune complexes compared with controls $(\mathrm{p}<0 \cdot 05)$. Serum immune complex levels paralleled disease activity and fell to normal levels in seven of the RV patients repeatedly tested after the institution of effective treatment.

The mean peripheral blood lymphocyte count was $1.22(\operatorname{SD~} 0.44) \times 10^{\%} / 1\left(\right.$ range $\left.0.26-2.24 \times 10^{9} / 1\right)$ and

Table 3 Comparison of immunological abnormalities in retinal vasculitis according to disease association

\begin{tabular}{|c|c|c|c|c|c|c|c|}
\hline \multirow{2}{*}{$\begin{array}{l}\text { Disease } \\
\text { associations }\end{array}$} & \multirow[t]{2}{*}{ Patient no. } & \multicolumn{4}{|c|}{ Immunoglobulin levels } & \multirow{2}{*}{$\begin{array}{l}\text { Immune } \\
\text { complexes }\end{array}$} & \multirow{2}{*}{$\begin{array}{l}\text { Lymphopenia } \\
\left(<1500 \text { cells } / \mathrm{mm}^{3}\right)\end{array}$} \\
\hline & & $\downarrow \operatorname{Ig} G$ & $\uparrow \operatorname{Ig} A$ & $\uparrow \operatorname{Ig} M$ & $\uparrow \operatorname{Ig} E$ & & \\
\hline Idiopathic & $\begin{array}{l}2,3,4,5,7,8 \\
13,14,17,19,21\end{array}$ & ${ }^{*} 2$ & $\mathbf{0}$ & 2 & 3 & 5 & 9 \\
\hline Behçet's syndrome & $\begin{array}{l}6,9,10,11,12 \\
18,20\end{array}$ & 3 & 1 & 2 & 3 & 6 & 6 \\
\hline SLE & 15,16 & 0 & 0 & 0 & 0 & 2 & 1 \\
\hline Sarcoidosis & 1 & 0 & 0 & 0 & 0 & 0 & 0 \\
\hline
\end{tabular}

${ }^{*}$ Figures refer to the number of patients having a particular immunological abnormality in each group. SI conversion: cells/mm ${ }^{3} \times$ $10^{6}=$ cells $/ 1$. 
this was significantly lower than the value for controls $(\mathrm{p}<0.005)$, with 16 patients having lymphopenia $\left(<1500\right.$ cells $\left./ \mathrm{mm}^{3}\right)$ at presentation $(\mathrm{p}<0 \cdot 005)$. T cell subset numbers were measured in six patients with idiopathic RV and five with Behçet's syndrome by means of monoclonal antibodies. The percentage of T cells (OKT3) was $72 \%$ (SD 10\%) for patients with idiopathic RV, 78\% (SD 15\%) for patients with Behçet's syndrome, and 77\% (SD 12\%) for controls. The T cell ratios of OKT 4 to OKT 8 cells were 2.0 and 1.8 respectively, which were similar to the value for the control group (1.9).

\section{Discussion}

Although a large variety of systemic diseases have been described in patients with retinal vasculitis, recent information suggests that only a small proportion of these diseases occur with a significant frequency in association with RV. In agreement with the findings of Dumonde et al. ${ }^{12}$ and Andrews et al." Behçet's syndrome was the most frequent disease seen in patients with RV, together with SLE and sarcoidosis. These diseases are idiopathic, with prominent immune abnormalities and a presumed immunological basis. The results of the present study support the concept that $\mathrm{RV}$ is an immunologically mediated disease.

Immunoglobulin abnormalities in $\mathrm{RV}$ were first reported by Koliopoulos et al..$^{21}$ and their observation of a raised serum IgM level in this disease was subsequently confirmed by Chilman ${ }^{22}$ and is similar to the findings of the present study. In contrast to previous studies, this study showed a significantly increased frequency of raised serum IgE levels and decreased IgG levels in patients with RV. These changes have not previously been reported in patients with RV. Raised IgE levels could be attributed to associated allergic diseases in two patients; the remaining four patients had no obvious cause for a raised $\operatorname{IgE}$ level and it was not associated with a peripheral blood eosinophilia.

The presence of circulating immune complexes (CIC) in a high proportion of patients with RV was first reported by Andrews et al. " and subsequently by Dumonde et al. ${ }^{12}$ The results of the present study confirm these earlier studies with $55 \%$ of patients tested having significantly increased serum immune complexes as detected by the $\mathrm{Clq}$ binding assay and $33 \%$ having cryoglobulinaemia. Immune complexes were more frequently detected in the sera of patients with associated diseases, particularly Behçet's syndrome, and were more often present in the sera of patients with associated uveitis and peripheral $R V$. No definite aetiological agent was identified in patients with RV, and there were no antigens which could be incriminated in immune complex formation, with the possible exception of DNA antibodies in patients with SLE.

Serum complement levels (C3 and $\mathrm{C} 4)$ and total haemolytic complement were either normal or increased in all patients with RV. The raised levels may reflect the role of these proteins as acute phase reactants, similar to the observed increased $\alpha-1$ antitrypsin levels recently reported by us in patients with active RV. ${ }^{23}$ Primary complement deficiency has been reported in several forms of vasculitis, including SLE. ${ }^{24}$ Andrews et al. ${ }^{11}$ reported decreased C3 levels in $24 \%$ of 17 patients with RV, and Dumonde et al. ${ }^{12}$ reported complement abnormalities of 'non-specific type' in the majority of their patients. These discrepant results may be due to several factors, including the timing of serum sampling, treatment regimen and the presence of an associated systemic vasculitis.

Other retinal autoantibodies have recently been reported in patients with RV. ${ }^{12}$ This is of considerable interest in view of the fact that experimental RV may be induced in certain primates following immunisation with retinal $\mathrm{S}$ antigen and the demonstration of subsequent development of serum retinal antibodies in these animals. ${ }^{25}$ Five patients with untreated RV were tested at presentation for the presence of retinal antibodies by an indirect immunofluorescent technique with human retina as the substrate. Retinal antibodies were not detected in this assay. The difference between these results and those of Dumonde et al. ${ }^{12}$ may be due to differences in methodology or may reflect the fact that such antibodies develop only after prolonged or severe ocular inflammation. Autoantibodies, including smooth muscle (SM), antinuclear (ANA), and gastric parietal cell (GPC) antibodies, have been reported previously in patients with RV. ${ }^{112}$ With the exception of the presence of antinuclear antibodies, which suggest an underlying connective tissue disease such as SLE, the signficance of other autoantibodies in RV is obscure. They may be an epiphenomenon or reflect ocular tissue damage, for example to vascular smooth muscle. Alternatively these immunological findings may reflect an immunoregulatory abnormality with increased $B$ cell activity secondary to change in regulatory $T$ cell subsets $\left(T_{H}\right.$ and $\left.T_{S}\right)$, as has been proposed in other vasculitides such as SLE..$^{24} 26$

This concept is supported by the observation that lymphopenia was the most common immunological abnormality at presentation, being detected in 16 patients. In the subsets of patients tested both $T$ and B lymphocytes were decreased, and there was no change in the ratio of helper to suppressor $\mathrm{T}$ cells. Although lymphopenia is a common manifestation of certain other vasculitic syndromes, such as SLE, ${ }^{24}$ it has not previously been reported in patients with RV. 
Lymphopenia was observed in 55\% (6/11) of patients with circulating immune complexes and the same proportion of patients with autoantibodies, while all patients with raised serum IgE levels were lymphopenic. Changes in T cell subsets may help to explain these observations, which may be secondary to a decrease in specific immunoregulatory $\mathrm{T}$ cells. Several mechanisms may be envisaged to explain this observation, including the presence of lymphocytotoxic antibodies, and this possibility is being examined.

The recent realisation of the association of $\mathrm{RV}$ with the HLA DR4 antigen ${ }^{27}$ indicates an immunogenetic predisposition to this disease, while the results of the present study in a small group of untreated patients with RV confirm the frequency of peripheral blood immunological abnormalities, especially immune complexes and lymphopenia, in this previously enigmatic disease and indicate the possible role of autoimmune mechanisms in the pathogenesis of retinal vasculitis.

\section{References}

1 Shikano S. Ocular pathology of Behçet's syndrome. In: International symposium on Behçet's disease, Rome, 1965. Basel, New York: Karger, 1965: 111-3.

2 Goldstein I, Wexler D. Ocular pathology of periarteritis nodosa. Arch Ophthalmol 1929; 2: 288-99.

3 Radda TM, Penhamberger H, Smolen J, Menzel J. Ocular manifestations of temporal arteritis. Arch Ophthalmol 1981; 99: 487-8.

4 Parsons-Smith G. Editorial. Ocular complications of temporal arteritis. Br Med J 1979; 1: 1443.

5 Gold DH, Morris DA, Henkind P. Ocular findings in systemic lupus erythematosus. Br J Ophthalmol 1972; 56: 800-4.

6 Bishko F. Retinopathy in systemic lupus erythematosus. A case report and review of the literature. Arthritis Rheum 1972; 15: $57-63$.

7 Maumenee AE. Retinal lesions in lupus erythematosus. Am J Ophthalmol 1940; 23: 971-81.

8 Aronson AJ, Ordonez NG, Diddie KL, Ernest JT. Immune complex deposition in the eye in systemic lupus erythematosus. Arch Intern Med 1979; 139: 1312-3.

9 Peress NS, Miller F, Pallu W. The immunopathophysiological effects of chronic serum sickness on rat choroid, plexus, ciliary process and renal glomeruli. J Neuropathol Exp Neurol 1977; 36: 726-33.

10 Howes EL, McKay DG. Comparison of ocular effects of circulating endotoxin and immune complexes; role of vasoactive amines. J Immunol 1975; 114: 734-7.

11 Andrews BS, McIntosh J, Petts V, Penny R. Circulating immune complexes in retinal vasculitis. Clin Exp Immunol 1977; 29: 23-9.

12 Dumonde DC, Kasp-Grochowska E, Graham E, Sanders MD Anti-retinal autoimmunity and circulating immune complexes in patients with retinal vasculitis. Lancet 1982; ii: 787-92.

13 Gerwurz H. Complement. In: Rose NR, Freidmand H, eds. Manual of clinical immunology. Washington: American Society of Microbiology, 1976: 36-47.

14 Platts-Mills TAE, Ishizaka K. Activation of the alternative pathway of human complement by rabbit cells. J Immunol 1974; 133: 348-53.

15 Kung PC, Goldstein G, Reinherz EL, Schlossman SF. Monoclonal antibodies defining distinctive human $T$ cell surface antigens. Science 1979; 206: 347-9.

16 Wakefield D. MD thesis. University of New South Wales, 1984.

17 ffytche TJ. Retinal vasculitis. Trans Ophthalmol Soc UK 1977; 97: 457-61.

18 Lyle TK, Wybar K. Retinal vasculitis. Br J Ophthalmol 1961; 45: 778-88.

19 Mason RM, Barnes CG. Behçet's syndrome with arthritis. Ann Rheum Dis 1969; 28: 95-103.

20 Cohen AS, Reynolds WE, Franklin EC, et al. Preliminary criteria for the classification of systemic lupus erythematosus. Bull Rheum Dis 1971; 21: 643-6.

21 Koliopoulos JX, Perkins ES, Seitanides BE. Serum immunoglobulins in retinal vasculitis. Br J Ophthalmol 1970; 54: 233-6.

22 Chilman T. Specific and nonspecific antibody activity in retinal vasculitis. Trans Ophthalmol Soc UK 1973; 93: 193-8.

23 Wakefield D, Easter J, Clark P, Breit SN, Penny R. Alpha 1 antitrypsin serum levels and phenotypes in patients with retinal vasculitis. Br J Ophthalmol 1985; 69: 497-9.

24 Sakane T, Steinberg AD, Green I. Studies of immune functions of patients with systemic lupus erythematosus. Arthritis Rheum 1978; 21: 657-64.

25 Salinas-Caroma MC, Nussenblatt RB, Gery I. Experimental autoimmune uveitis in the athymic nude rat. Eur $J$ Immunol 1982; 12: 480-4.

26 Agnello VM, de Bracco ME, Kunkel HG. Hereditary C2 deficiency with some manifestations of systemic lupus erythromatosus. J Immunol 1972; 108: 837-42.

27 Wakefield D, Lane J, Penny R. Retinal vasculitis associated with HLA DR4. Hum Immunol 1985; 14: 11-8.

Accepted for publication 29 August 1985. 